\title{
横方向不均質媒体における波動場の最新の計算法
}

\author{
—ガウシアンビームを中心として——
}

\author{
スタンフォード大学地球物理学教室 蓬 田＼cjkstart清
}

\section{State-of-the-art Computational Techniques for Wavefields in Laterally Heterogeneous Media: Mainly the Gaussian Beam Method}

\author{
Kiyoshi Yomogida \\ Department of Geophysics, Stanford University, Stanford, California 94305, U.S.A. \\ (Received December 26, 1988; Accepted February 20, 1989)
}

\begin{abstract}
This paper reviews recent developments in computational techniques for wavefields in laterally heterogeneous media, mainly the Gaussian beam method. We start with a solution by the asymptotic ray theory as a high-frequency limit, and point out two major defaults in this approach. The first problem is a two-point ray tracing or time-consuming search for the ray connecting source and receiver. This difficulty can be removed by the paraxial ray approximation, extrapolating wavefields outsides of rays. The second is due to singularity in some critical regions such as caustics and shadow zones. By combining a point-source wave with a plane wave, the Gaussian beam method can avoid such singularity. Also, superposition of many beams naturally smooths out heterogeneities of media, simulating the effect of finite wavelength. In laterally homogeneous media, this superposition corresponds to the WKBJ seismogram of Chapman as a limit. The real difficulty lies in ambiguous weighting factors for the two wavefields: a point-source wave and a plane wave. No studies have ever revealed any physical basis to find appropriate values of the weighting factors. In the near future, one must develop any method to globally estimate those values, rather than empirically, by matching boundary conditions of wavefields on free surface or on interface, which will eventually give more reliable results.
\end{abstract}

\section{$\S 1$.はじめに}

2 次元並びに 3 次元不均質媒体における弾性波の伝播 を計算する方法が, 各種の雑誌や会議で最近盛んに取り 上げられるようになってきた。このような流れは，観測 データの精度が上がるにつれて, 深さ方向にのみ構造が 変化する従来のモデルに基づく計算，あるいは波線理論 に基づく走時異常だけを使った研究では不満足な結果し か得られなくなってきたことによると思われる．確立さ れた手法はいまだにみつかってはいないものの，これま での研究を通じて，おおよその方向は明らかになってき ている，本論では，方法及び文献をできる限り網羅する のではなく，著者も関わり又現在最も普及しているガウ シアンビーム法（以下 GB 法と略す）について論じるこ とにする， GB 法に関する総論及び各種の応用について は, 開拓者であるČERVENÝ の二つの論文 [ČERVENÝ (1985a，1985b)] を参照してあらうことにして，ここで
は GB 法の基本的概念をできるだけわかりやすく解説 し,さらに残された問題点とその解決への展望について 述べる。

\section{§ 2. GB 法の位置づけ}

不均質媒体中の弾性波伝播に関する問題を取り扱う際 には，波長，伝播距離，不均質性の空間スケールといっ た三つのパラメーターに応じて，有効な方法を選択しな くてはならない.これらの関係は Fig. 1 [AKI and RICHARDS (1980)] のようにまとめられる. 波長之不均質性 のスケールが同じくらい $(k a \sim 1)$ の場合は, 回折等の複 雑な挙動が顕著になる。 あし伝播距離が波長に比べてあ まり大きくなければ $(k L<100)$, 現在のコンピューター の能力でも弾性運動方程式そのあのを有限要素法や差分 法などの純数值的方法で解くことが可能であり，結果も 正確である．震源付近での強震計の低周波成分や地球の 


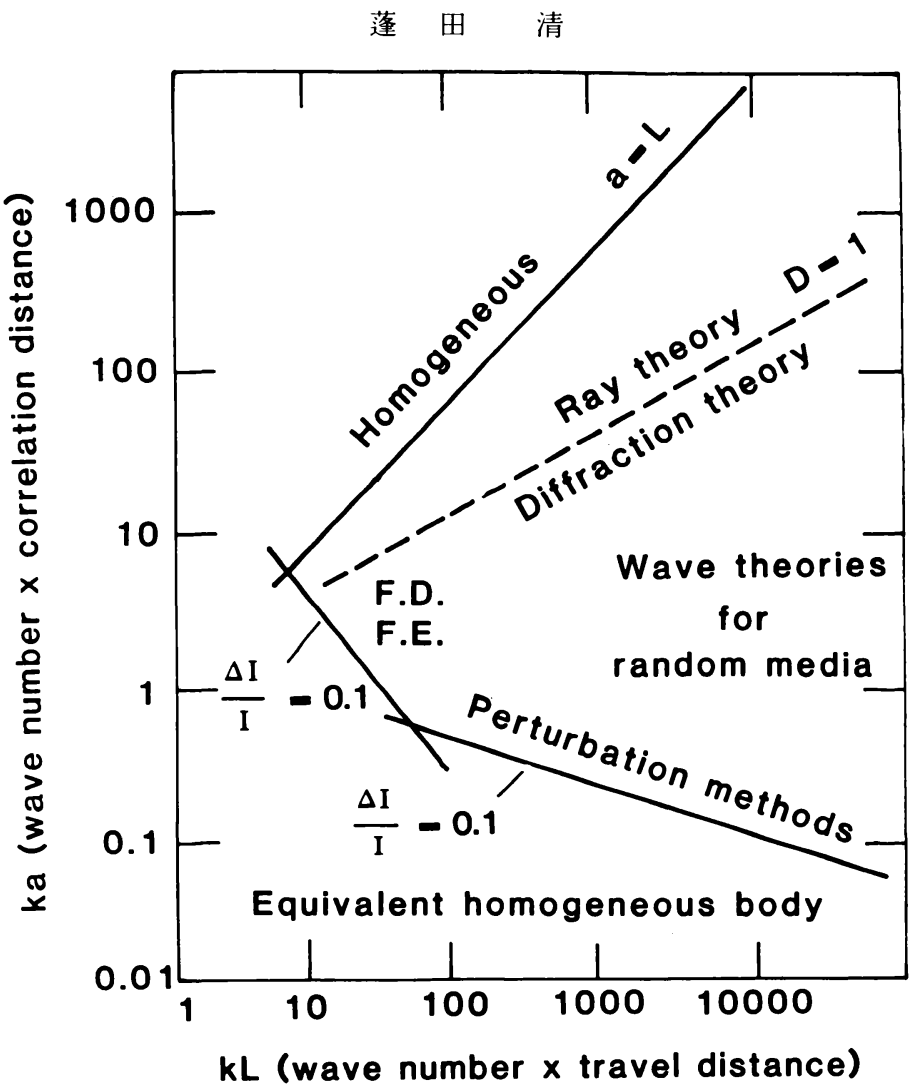

Fig. 1. Classification of scattering problems and applicable methods in $k a-k L$ diagram [reproduced from Fig. 13.11 of AKI and Richards (1980)].

自由振動の低次モードなどでは，この方法が使用でき る. 伝播距離が長くなると、こうした決定論的な方法は もはや適用できなくなり，その物理的意味も失ってい く.このような場合には, 確率論的方法で十分満足でき る結果が得られるようになる.コーダ波はその一例であ る.一方, 高周波の波の伝播を扱う場合，すなわち波長 が不均質性のスケールよりずっと小さい場合 $(k a>10)$ には, 幾何光学の理論が適用される.これは, 屈折法に よる地殼構造の研究, あるいは走時曲線を用いた全地球 的内部構造の決定など, 地震学誕生以来最も広く用いら れてきた方法である. 走時が主役を演じるが，振幅も一 応計算することができる.

最後の方法はフェルマー (Fermat) の原理に基づく理 論体系であり, 波線理論と呼ばれている.これに対して, 前の二つの方法は弾性運動方程式を基礎としており, 波 動理論と呼ばれている. 波線理論は簡単で地震学の多く の現象に適応できるが, 回折等の現象は全く説明できな い. GB 法は波線理論から出発し（それは開拓者のČ VENÝが波線理論の大家であることにもよるが), 波動理 論のすぐれた点も取り入れ，その適用範囲を広げようと
するものである，以下では，まず波線理論の拡張として の GB 法を導き，次にそれが波動理論とどのように結び ついているかを示す.

\section{§ 3. 漸近波線理論}

光学の分野では, 波動方程式のある漸近解が波線や波 面といった幾何光学の概念に対応づけられることが古く から示されていた [例えば, BoRN and WolF (1980)の 第 3 章， あるいは LANDAU and Lifshitz (1975) の第 7 章]. 弾性波に対してもこの関係が成り立つことが明確 に示されたのは，実は 1950 年代後半になってからのこ とである [BABICH and Alekseyev (1958), KARAL and KELLER (1959)]. ここでは, 議論を簡単化するため, 最 も単純な 2 次元スカラー波動方程式

$$
\left(\frac{1}{c^{2}} \frac{\partial^{2}}{\partial t^{2}}-\nabla^{2}\right) U(x, z, t)=0
$$

のみを考えることにする. ここで速度 $c$ は座標 $(x, z)$ に 依る. $t$ は時間で, $\nabla^{2}$ は 2 次元ラプラシアン, そして $U$ は波動場で一般的な複素数とみなす．弾性波及び 3 次元 問題については, CERVENY (1985a) を参照されたい。た 
だし基本的な取り扱いは全く同じである.

均質体における(1)の解として, 平面波

$U(x, z, t)=a e^{i \omega(\boldsymbol{p} \cdot \boldsymbol{x}-t)}$

があることは自明である. ここで, 振幅 $a$ は定数であ り, $\omega$ は角周波, そしてスローネスベクトル (slowness vector) $\boldsymbol{p}$ は大きさは速度の逆数 $1 / c$ で, 方向は波の伝 播方向に一致する. これに対して, 不均質体においては 波の振幅も伝播方向も変化するので, これらを座標 $(x$, z) の一般的な関数としなくてはならない. 高周波領域で は波面の近傍において位相が最も激しく変化するはずで あるから，座標 $(x, z)$ における波面の到着時刻すなわち 走時 $\tau(x, z)$ を導入することで，位相を表すことにする. そこで,(1)の高周波領域における漸近解

$$
U(x, z, t)=A(x, z) e^{i \omega(\tau(x, z)-t)}
$$

の形が与えられる。(2)を(1) に代入し, 高周波近似とい うことで，角周波数 $\omega$ の高いオーダーの項のみを考え る.一番大きな $O\left(\omega^{2}\right)$ の項では,

$$
(\nabla \tau)^{2}=\frac{1}{c^{2}}
$$

という走時 $\tau$ を決める eikonal 方程式が得られ，次の $O(\omega)$ の項からは

$$
A \nabla^{2} \tau+2 \boldsymbol{\nabla} A \cdot \boldsymbol{\nabla} \tau=0
$$

という振幅 $A$ を決める transport 方程式が得られる.

まず，(3)より $\boldsymbol{p}=\boldsymbol{\nabla} \tau$ というべクトルを導入する. こ のベクトルの大きさは, (3) より直ちに速度の逆数であ

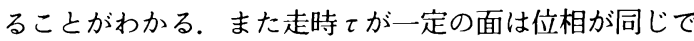
あり，従って波面に対応することがわかる． $\boldsymbol{p}$ は定義か らこの波面に常に直角方向を向いていることになり，物 理的には波線の方向に対応しているわけである．従って $\boldsymbol{p}$ は平面波の場合に定義したスローネスベクトルを一般 化したものであることが示される，x を示すむのとして, $s$ をその波線に沿っての長さとする と, $d \boldsymbol{x} / d s$ は明らかに単位べクトルで, その方向は波線 の接線方向である. $\boldsymbol{p}$ と同じ方向であるから

$$
\frac{d \boldsymbol{x}}{d s}=c \boldsymbol{p}
$$

が求まる.一方， $\boldsymbol{p}$ を波線に沿って微分すると，

$$
\frac{d \boldsymbol{p}}{d s}=\frac{d}{d s}(\boldsymbol{\nabla} \tau)=\boldsymbol{\nabla}\left(\frac{d \tau}{d s}\right)=\boldsymbol{\nabla}\left(\frac{1}{c}\right)
$$

が得られる. ここでは $s$ の定義と (3) より $d \tau / d s=1 / c$ を用いた。 以上の二っの式（波線トレース式）から波線 の軌跡を決めることができる.さらに, 走時 $\tau$ が波線 $(0 \rightarrow s)$ に沿っての速度の逆数の積分

$$
\tau(s)=\int_{0}^{s} \frac{d \xi}{c(\xi)}=\int_{0}^{s} p \cdot d x
$$

という基本的な式が得られる.
次に，振幅について考える，まず，波線上の各点にお いて波線の接線方向之法線方向に座標軸を持つ波線座標 系 $(s, m)$ を定義する. $s$ 及び $m$ に対応するスケールファ クターを 1 及び $Q$ とすれば, 走時のラプラシアンは

$$
\begin{aligned}
\nabla^{2} \tau & =\frac{l}{1 \cdot Q} \frac{\partial}{\partial s}\left(\frac{Q}{1} \frac{\partial \tau}{\partial s}\right)+\frac{l}{l \cdot Q} \frac{\partial}{\partial m}\left(\frac{m}{Q} \frac{\partial \tau}{\partial m}\right) \\
& =\frac{1}{Q} \frac{d}{d s}\left(\frac{Q}{c}\right)
\end{aligned}
$$

となる.ここでは, (3) と波線座標系の定義から $\partial \tau / \partial s=$ $1 / c$, また $\partial \tau / \partial m=0$ (走時 $\tau$ は波線の法線方向には一 定）であり， $Q$ は $s$ のみ関数として偏微分より全微分 になおした， $m$ のスケーリングファクター $Q$ は, 物理的 には近接した波線どうしの広がりを表す量で, geometrical spreading と呼ばれるものに相当する. 上の式を 用いれば，(4)は

$$
\frac{d}{d s}\left[\frac{Q}{c} A^{2}\right]=0
$$

と簡単に表せる.これは, $Q A^{2} / c$ が波線に沿って一定で あること, すなわち, 波線の管の中のエネルギーの流れ が保存されることを示している. (3) と (4) が以上のよう に解け，(2)の漸近解として

$$
U(s, t)=\Phi \sqrt{\frac{c(s)}{Q(s)}} \exp \left\{-i \omega\left(t-\int_{0}^{s} \frac{d \xi}{c(\xi)}\right)\right\}
$$

が得られる. ただし， Фは定数である. これが, Asymptotic ray theory（以下 ART と略す）の基本式であ る. (6) の物理的意味は簡単である. すなわち, 位相の遅 れは波線に沿っての走時であり, 振幅は波線の管の断面 積 $Q$ の平方根に反比例する. ここで, 位相は (3) より走 時の一階微分 $\nabla \tau$ によって求まるのに対し，振幅は二階 微分 $\nabla^{2} \tau$ によることに注意すべきである，つまり，振幅 の方が微細な速度構造に敏感であり, 逆に言うと扱いが はるかに難しくなるわけである. とにかく, 地震学の多 くの問題は, (6) の形式化に基本的には依存している.

\section{§ 4. Paraxial Ray 近似}

(6) の表現式は応用上大変有用であるが, 次の二つの 重大な欠点を含んでいる. a) 震源と観測点を結ぶ波線を うまくみつけなければ使えない，媒質が複雑でさらに 3 次元のような場合においては，これはきわめて大変な作 業である. b) 波線が届かないような陰の領域 (shadow zone) では適用できないし，また，波線が重なりあう焦 点 (caustic) では, 波線の管の広がり $Q$ が零となり, 解 が発散する.このような場所は波動場の特異領域と呼ば れ，ART は使用できない，特異領域の各例については CHAPMAN (1985) が簡潔にまとめている. まず a) の問題について考えよう。この問題について 
清

は，C CRVEN Ý等が明快な解決法を一応与えている[例え ば, Červený and PŠenčí́ (1983), Červený et al. (1984)]．彼らの解決法は, ARTで計算される波動場を 波線以外の領域に外挿する paraxial ray approximation（以下 PRA と略す）の考えに基づいている. 波線上 のある点 $s$ に近接した点 $s_{1}$ の走時 $\tau\left(s_{1}\right)$ を点 $s$ のまわり のティラー展開によって表すと

$$
\tau\left(s_{1}\right) \simeq \tau(s)+\boldsymbol{\nabla} \tau(s) \cdot \boldsymbol{x}+\frac{1}{2} \boldsymbol{x}^{\mathrm{T}} \boldsymbol{N} \boldsymbol{x}
$$

となる.ここで, $\boldsymbol{x}$ は $s$ から $s_{1}$ を結ぶべクトルであり, 行列 $\boldsymbol{N}$ は走時の二階微分 $\left(N_{\mathrm{ij}}=\partial^{2} \tau / \partial x_{\mathrm{i}} \partial x_{\mathrm{j}}\right)$ を波線上の 点 $s$ で求めたものである. 前章で示したように, 走時曲 線 $\tau$ 之波線の関係から, $\nabla \tau$ は大きさが速度の逆数, 方向 が波線の接線方向というスローネスベクトル $\boldsymbol{p}$ である. (7) の展開では, $\boldsymbol{x}$ の 2 次の項まで採用しているが, この ことは, 物理的には波線近傍の複雑な形をした波面を放 物線によって近似していることに相当する．近似の精度 は, 考えている点 $s_{1}$ がどのくらい波線に“近い”かに依 存しており, ČERENÝ (1985a) の詳しい議論によれば, 半波長程度以内, さらに正確には第一フレネルゾーンの 中であれば十分よい近似になる。この放物線による波面 の近似は，物理探查などでは既にその有効性が示されて いる [例えば Claerbout (1985)].

残る問題は，走時の二階微分 $N_{i j}$ をどのように求める かである. 議論を簡単にするため, 新たに ray-centered 座標系 $\boldsymbol{q}=(s, n)$ を導入する. 前章で用いた波線座標系 $(s, m)$ では，考えている点を実際に通過する波線を考え， その波線に沿っての長さ $s$ と法線方向の座標 $m$ を考え た．別の点を考える際には，その点を通る別の波線を基 に座標系を考えなくてはいけない，従って，mのスケー リングファクターQが波線の管の広がりを示すわけで ある. これに対してここで考える座標系 $\boldsymbol{q}$ では, 点の位 置に関係なく，まず特定の波線を考える，波線は考えて いる点の近傍を通過するだけである．この点から波線に 垂線を下し，その長さを $n$ とする. そして波線に沿って のこの交点までの長さを $\mathrm{s}$ とする，考えている点が波線 上にある場合にのみ，上の二つの座標系は一致する．詳 しくは CERVENÝ (1985a) を参照されたい.

(7) の二次の項は座標系 $\boldsymbol{q}$ を用いれば

\section{$\boldsymbol{x}^{\mathrm{T}} \boldsymbol{N x}=\boldsymbol{q}^{\mathrm{T}} \boldsymbol{M q}$}

となり, 各要素は簡単に, $M_{11}=\partial^{2} \tau / \partial^{2} s=\partial(1 / c) / \partial s$, $M_{12}=M_{21}=\partial^{2} \tau / \partial n \partial s=\partial(1 / c) / \partial n, M_{22}=\partial^{2} \tau / \partial n^{2}$ とな る. $M_{22}$ 以外の各要素は, 単にモデルのスローネス $(1 / c)$ の空間微分である. 波線上の点では $s$ 之 $n$ のスケーリン グファクターは共に 1 になるので, $\nabla^{2} \tau$ と波線の広がり $Q$ が次の式

$$
\begin{aligned}
\nabla^{2} \tau & =\frac{1}{Q} \frac{d}{d s}\left[\frac{Q}{c}\right]=\frac{\partial^{2} \tau}{\partial s^{2}}+\frac{\partial^{2} \tau}{\partial n^{2}} \\
& =\frac{\partial}{\partial s}\left(\frac{1}{c}\right)+M_{22}
\end{aligned}
$$

で関係づけられていたことを思い出せば、

$$
M_{22}=\frac{1}{Q c} \frac{d Q}{d s}
$$

となり, 振幅を決める波線の広がり $Q$ を用いて, 残りの $M_{22}$ あ表現できる. ここで，(7) に戻って走時 $て$ が一定の 面が波面であることを思い出せば， $M_{22}$ は物理的には波 面の曲率を表していることがわかる. 波線の広がり $Q$ が 波面の曲率 $M_{22}$ と上式のような深い関係にあることは, 次のように理解できる，例えば，波線近傍の波動場が平 面波の場合は, 波面の曲率は零, 従って上式より波線の 広がり $Q$ は一定, つまり波線と波線の間隔は変わらない という, 平面波の特徴を表している。一方, 波線が一点 に集まる焦点の場合は，曲率 $M_{22}$ が無限大であり，徙っ て波線の広がり $Q$ は零という,これまた妥当な結論が導 かれる，一般の波動場はこの二つの場合の中間にあると 考えられる. 後で述べるように, GB 法は, 平面波と円筒 波（3 次元では球面波）の線型結合を用いて，より一般 的な波動場を表現しようというものなのである。このア イデアは大変素晴らしいものであるが，実は，この結合 をどのようにしていくかという所があいまいな点として 残っている.これが現時点における GB 法の最大の問題 点なのである。

以上でいかにもきれいに定式化できたように見える が, 波面の曲率 $M_{22}$ を具体的によ゙のように計算していく かがまだ問題として残っている．寒を言えば，ARTの 式 (6) を示す過程で, どうやって波線の広がり $Q$ を求め るかを省略していた， $Q$ と $M_{22}$ との間にはある関係が存 在するので, ART の (6) の解を求めることと (7) の走時 の近似式を用いることは，計算量は全く同じである. APT の解に比へて，(7)の近似において特に余計な計算

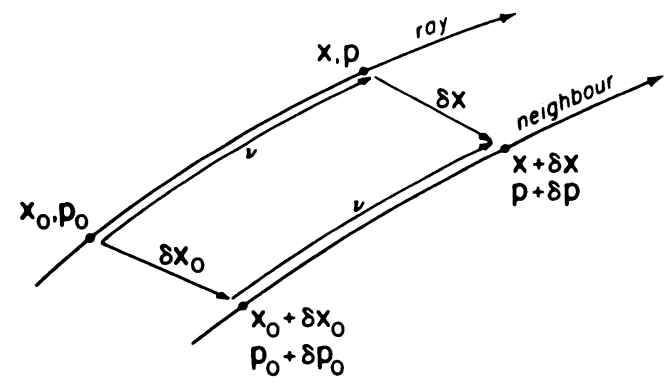

Fig. 2. A ray and its perturbation with $\delta \boldsymbol{x}$ and $\delta \boldsymbol{p}$ [reproduced from THOMSON and CHAPMAN (1985)]. 
は必要ないのである. 波線の広がり $Q$ は近接した波線同 土がいかに変化するかによるので, ある一本の波線の軌 跡を記述する (5) の $\boldsymbol{x}$ と $\boldsymbol{p}$ を摂動させてみればよい (Fig. 2). その結果として, 次式を得る.

$$
\begin{aligned}
& \frac{d \delta \boldsymbol{x}}{d s}=c \delta \boldsymbol{p} \\
& \frac{d \delta \boldsymbol{p}}{d s}=-\frac{1}{c^{2}} \boldsymbol{V} \delta \boldsymbol{x}
\end{aligned}
$$

ここで, 行列 $\boldsymbol{V}$ の各要素は速度の二階微分である.ここ での撕動は波線に対して法線方向にのみ, ずらしたこと になるので，2 次元の場合は， $\delta \boldsymbol{x}$ と $\delta \boldsymbol{p}$ はスカラーにな る. Fig. 2 から直ちにわかるように, 波線の位置の摂動 $\delta \boldsymbol{x}$ が，実は波線の広がり $Q$ に他ならない，そこで， $\delta \boldsymbol{x}$ を $Q, \delta \boldsymbol{p}$ を新しい変数 $P$ で置きかえると

$$
\begin{aligned}
& \frac{d Q}{d s}=c P \\
& \frac{d P}{d s}=-\frac{1}{c^{2}} \frac{\partial^{2} c}{\partial n^{2}} Q
\end{aligned}
$$

が得られる. CERVENÝ等は，波線の軌跡を記述する (5) に対比して，波線相互のふるまいを記述する(8)を dynamic ray-tracing と呼んでいる.この式より, 波面の 曲率すなわち走時の二階微分 $M_{22}=P / Q$ が求められる. 3 次元問題では $P$ と $Q$ は行列になるが, その場合につい ては CERVENY (1985a) を参照されたい. なお，振幅につ いては走時の変化に比べてゆるやかに変化するので, (7) の二次のオーダーまでの展開では, 波線上の点 $s$ とその 近傍の点 $s_{1}$ で同じ值をとるとしてよいことが, ČERVENÝ (1985a) による厳密な計算によって示されている.

以上の議論をまとめると, PRA では, 波線近傍の点 $s_{1}$ における解は, 波線上の点 $s$ での解 (6) を拡張して, 次 のように表現できる.

$$
U\left(s_{1}, t\right)=\Phi \sqrt{\frac{c(s)}{Q(s)}} \exp \left\{-i \omega\left(t-\tau\left(s_{1}\right)\right\}\right.
$$

ここで

$$
\tau(s)=\int_{0}^{s} \frac{d \xi}{c(\xi)}+\boldsymbol{p}(s) \cdot \boldsymbol{x}+\frac{1}{2} \boldsymbol{q}^{\mathrm{T}} \boldsymbol{M q}
$$

この形式においては, 波線が希望の点を通らなくても, その近くを通っていさえすれば，かなりよい精度で波動 場が計算できることになる. ČERVENÝ等の初期の定式化 [例えば CERVENÝ et al. (1982)] では, 波線から法線方向 $n$ による展開のみであったために，考えている点から波 線上に垂線をおろした点の座標を求めなければならず, 実際の計算では，この作業に手間が結構かかった. (9)の 表現を用いれば, そのような厳密な計算は必要なく, 波 線上で近い点ならどこでもよいことになる.

CERvenY et al. (1984) は, さらに次のような関係式を
PRA より導いた. (7) の走時の表現を $\boldsymbol{x}$ で微分すると,

$$
\boldsymbol{p}^{\prime}(0) \simeq \boldsymbol{p}(0)+\nabla\left(\frac{1}{c(0)}\right) Q(s)^{-1} n
$$

という式を得る. $\boldsymbol{p}(0)$ は出発点におけるもとの波線の方 向, いわゆる射出角 (take-off angle) であり, $\boldsymbol{p}^{\prime}(0)$ は出 発点から求めている点へ波線を通すための新しい射出角 である.すなわち，この式は，波線が求める点に当たら ない場合に，射出角を出発点でどのように補正すればよ いかの目安を与える. 波線で二点を結ぶというのは地震 学では最も基本的な過程のひとつではあるが, 計算を実 際したことのある人なら誰でもわかるように，この計算 はとても難しい. PRA は波線を単に考えている点の近 くを通すだけで (9) によりその点の波動場を計算できる のだが，精度のことを考えると，できるだけ近くに波線 をもっていった方が望ましい.（10)の関係式は，この作 業をどのように補正していくかの指針を与える．著者の 経験によれば, (10) を用いると, ほとんどすべての場合 数回の補正で収束し，二点を十分な精度で結びつける望 みの波線が得られる.この(9) と(10)を組み合わせるこ とは実用上大変有効であり, 今後, 従来の波線の計算方 法に取って代わることが予想される. 実際のデー夕処理 に，この方法は積極的に利用されるべきである.

\section{§ 5. GB の荓入}

前章の初めに言及した ART (6) の二つの重大な欠点 のうち, 一番目のもの (波線と走時の計算) はPRA で十 分に解决されうることを示した. しかし, PRA を用いて む, むうひとつの欠点, すなわち, 特異領域における波 動場の計算に伴う困難は解決できない，何本かの波線が 一点に集まってくる焦点の場合には，波線の管の広がり $Q$ が零となり，(9) の形式においても振幅が無限大に なってしまう。このような場合は，今までの議論で用い てきた角周波数が無限大という仮定が破綻をきたしてし まう. 従って, 有限の周波数の効果, あるいは波動場の 周波数依存性を考える必要がある. 振幅を決める (4) は, 波線の管の中のエネルギーの流れが一定という, 周波数 が無限大あるいは波長が無限小の場合を考えている．エ ネルギーが完全に波線の管の中に閉じ込められていると しているのである. あし波数が有限, つまり波長が有限 の場合には, エネルギーが管の外へと染み出しているは ずである. 特に, 焦点のように管の断面積が零になるよ うな領域では，こういった染み出しの効果が支配的にな る.これが(9)の形式化が破綻をきたしてしまう物理的 説明である.このような効果を考慮しようとすると, 一 本の波線だけではなく, 考えている点の近傍を通過する 波線からの寄与む勘定に入れなければならない，すなわ 
ち，一本の波線だけによる波動場の表現ではなく，多く の波線からの寄与をたし合せることにより, 波動場を計 算していくことが要請される.

有限の周波数の場合には, 波線の管からエネルギーが 染み出すが，その程度は波線から遠ざかるにつれて減衰 すると考えるのが物理的に正しいであろう．PRA(9)の 表現で波線からの距離 $n$ に対応する部分は

$$
\exp \left(i \frac{\omega}{2} M_{22} n^{2}\right)=\exp \left(i \frac{\omega}{2} \frac{P}{Q} n^{2}\right)
$$

である.そこで， $M_{22}$ を実数ではなく複素数 $M_{22}=$ $\operatorname{Re} M_{22}+i \operatorname{Im} M_{22}$ であるとすれば, 振幅は, $\exp (-(\omega / 2)$ $\left.\operatorname{Im} M_{22} \cdot n^{2}\right)$ となる。もし $\operatorname{Im} M_{22}$ が正ならば, 振幅が波線 からの距離に対して誤差関数のように減衰していくこと になる．これが，以下の方法をガウシアンビーム (Gaussian Beam) と呼ぶ由縁である。この種の定式化は, レーダーや光学の分野では回折等の問題に比較的古くか ら考案されていた [例えば, KogeLnIK (1965), DeschAMPS (1971)].これらの応用では一本のビームのみで波 動場を表現しようとしてきたが, 地震学に必要なより複 雑な媒質には直接使えない. CERVENÝ等の功績は, 従来 の平面波分解 [AKI and RICHADS (1980) § 6.1 を参照の こと] の形を GB 法と組み合わせることによって, 一本 のビームの概念に留まらず，何本すのビームのたし合わ せにより波動場を表現しようとした点である。平面波分 解は, 地震学でよく用いられる深さ方向にのみ構造の変 化する媒質モデル（一次元モデル）の波動場を記述する のに用いられるが， GB 分解によって，横方向にも不均 質なモデルにまで拡張できることになる。この点につい ては次章で詳しく述べることとし，その前に，まず，一 本のビームの意味, 具体的には複素数变数 $M_{22}=P / Q$ を どのように取り入れるかについて考える.

$M_{22}$, つまり $P$ と $Q$ を複素数とみなすのは，これらの 変数が dynamic ray-tracing (8) の解であり, 実数から の解折接続という数学的妥当性にもよる. 類似の例とし ては，完全弾性体に減衰の効果を導入する際に，速度を 実数から複素数にする場合なら゙がある.これからは, 変 数 $P$ と $Q$ は (8) の複素数解であるとする. これらを複素 数とする際に, (8) が二連一階連立微分方程式であり, 独 立な解が二組存在することに注意する必要がある，P $Q$ を二組の独立な初期条件の解（実数）の線型結合で表 し，その係数を複素数とすれば，物理的にもわかりやす いであろう. ČERVENÝ (1985a) 等に従い, 初期条件は, 平面波の場合

$$
P_{1}(0)=0, \quad Q_{1}(0)=1
$$

と, 円筒波あるいは線震源（3 次元では球面波あるいは 点震源）の場合

$$
P_{2}(0)=1 / c(0), \quad Q_{2}(0)=0
$$

とする.ここで, 波面の曲率 $M_{22}$ は，それぞれ零と無限 大になることを思い出していただきたい，なお，MADARIAGA (1984) は, 不均質性のある媒体について, 異なっ た形の平面波の初期条件を提唱している. ARTやPRA では，このいずれか一方を初期条件として (8) を波線に 沿って解いていけばよい，点震源とみなせる地震からの 波では, 後者を使うが当然である. ČERVENÝ et al. (1982)は，線型結合の具体的な形として次のものを採用 している.

$$
\begin{aligned}
& P(s)=\varepsilon P_{1}(s)+P_{2}(s) \\
& Q(s)=\varepsilon Q_{1}(s)+Q_{2}(s)
\end{aligned}
$$

ただし， $\varepsilon=s_{0}-i L_{0}^{2}$ である.これで $P / Q$ の虚数部は望み の正となる.

二組の独立な解に対しては (8) から

$$
\frac{d}{d s}\left[Q_{2}(s) P_{1}(s)-Q_{1}(s) P_{2}(s)\right]=0
$$

が成り立つことが示される，特に，(11)の初期条件を満 たす場合には，

$Q_{2}(s) P_{1}(s)-Q_{1}(s) P_{2}(s)=$ const. $=1 / c(0)$ となり，ロンスキアンが正值をとることが示される. (11) のような初期条件下では, $Q_{1}(s)$ と $Q_{2}(s)$ が同時に零 になることはない，すなわち，それらの線型結合である $Q(s)$ は絶対に零にはならないことを上式は意味してい る.これが二組の独立な解の線型結合で $P(s)$ 及び $Q(s)$ を表現する重大な利点である，Q(s) が零にならない限 り，解の形 (9) より，これが発散することはない，物理的 には，円筒波源に対して焦点になる点と平面波源に対し て焦点になる点は常に異なっていることに対応してい る. 初期条件 (11)の一方のみで実際の波動場を表そうと して特異領域を生み出してしまう ART に対して, GB 法は, 円筒波源（あるいは球面波源）と平面波源のたし 合わせで表現し, 解がいつも安定するようにしているの である. Chapman and Drummond (1982) は, 古くから 応用数学や量子力学で用いられている Maslov 法を地震 学に導入したが，これも実は球面波源 ( $\boldsymbol{x}$-平面) と平面 波源（p-平面）の二つの組み合わせによるもので，その 基本は $\mathrm{GB}$ 法と同じである. 普通の $\boldsymbol{x}$-空間上では波動 場が特異（つまり焦点）になるが， $\boldsymbol{x}$ と $\boldsymbol{p}$ を合わせた位 相空間上ではリュービルの定理から特異点が消えてしま うことを利用する．これがまさに GB 法の (13) に対応し ているわけである。なお, Maslov 法については, Thomson and Chapman (1985) 及び Chapman (1985) による良いまとめがある。 


\section{§6. GB のたし合せと平面波分解}

前章では, 複素変数 $P$ と $Q$ を導入することによって, 一本の波線が特異点のない物理的にも妥当な GBになる 過程をみてきた。ここでは，何本もの GB のたし合せが 波動理論に基づく合成地震記象といかに関係するかをみ ることにする.

まず，二次元均質媒体における円筒波の平面波分解か ら入るとわかりやすい. このような場合のグリーン関数 は第一種ハンケル関数で与えられ，それを積分 $[\mathrm{AKI}$ and RICHARDS (1980) §6.1 を参照のこと] で表すと次 のようになる.

$$
\begin{aligned}
U(\boldsymbol{x}, \omega) & =\frac{i}{4} H_{0}^{(1)}\left(\frac{\omega}{c} r\right) \\
& =\frac{i}{4 \pi} \int_{-\infty}^{\infty} \frac{e^{i \omega(p \boldsymbol{x}+\eta|z|)}}{\eta} d p
\end{aligned}
$$

ただし， $r=\left(x^{2}+z^{2}\right)^{1 / 2}$ は波源からの距離, $p=\sin \phi / c$ （角度 $\phi$ は $z$ 軸に対する波の伝幡方向）は波線パラメ一 ター, $\eta=\left(c^{-2}-p^{2}\right)^{1 / 2}=\cos \phi / c$ は垂直方向のスローネ スである.なお, $p$ が $c^{-1}$ より大きい時には, $\eta$ の虚数部 が正符号をとるように定義し, 垂直方向に減衰する波も 含むようにする. pの代わりに角度 $\phi$ を変数ととれば

$$
U(\boldsymbol{x}, \omega)=\frac{i}{4 \pi} \int_{c} e^{i \omega(p x+\eta|z|)} d \phi
$$

となり，積分路 $c$ は $(-(\pi / 2)-i \infty)$ から $((\pi / 2)+i \infty)$ ま でである. このような分解を行うのは, 地震学でよく扱 われる深さ方向のみの一次元モデルでは円筒波や球面波 のふるまいが複雑になるからである. スネルの法則よ り, どんな速度勾配や不連続面があってもパラメーター $p$ は特定の波線に沿って不変であるから, Weyl 積分 (14)の被積分関数は，その形が保たれ都合がよい．特定 の $p$ の值に対応する被積分関数 $\exp \{i \omega(p x+\eta|z|)\}$ の ひとつひとつは, $z$ 軸からの角度 $\phi$ の方向に伝幡する平 面波に対応している. 横方向不均質性が入ってくると, pのように伝幡において不変に保たれるような変数が, あはや存在しなくなる. 従って, 上で述べた平面波分解 あ全く意味がなくなるが，(14)の特定の $p$ に対応する平 面波を GB で置き換えれば，横方向不均質がある場合へ の自然な拡張になるであろうことが期待される. (9)の 表現を用いれば,

$$
U(\boldsymbol{x}, \omega)=\frac{i}{4 \pi} \int_{c}\left[\frac{Q(0) c(s)}{c(0) Q(s)}\right]^{1 / 2} e^{i \omega \theta(\boldsymbol{x}, z, \phi)} d \phi
$$

ただし，

$$
\theta(x, z, \phi)=\int_{0}^{s} \frac{d \xi}{c(\xi)}+\boldsymbol{p}(s) \cdot \boldsymbol{x}+\frac{1}{2} \boldsymbol{q}^{\mathrm{T}} \boldsymbol{M q}
$$

となり,ここで $M_{22}=P / Q$ は (12)で与えられる複素変 数である. 実際の計算では, いろいろな方向 $\phi$ に放出し
た有限の数のビームをたし合わせることで， (15a) を評 価する.すなわち,

$$
U(\boldsymbol{x}, \omega) \simeq \frac{i}{4 \pi} \sum_{\phi}\left[\frac{Q(0) c(s)}{c(0) Q(s)}\right]^{1 / 2} e^{i \omega \theta(x, z, \phi)} \Delta \phi
$$

ただし， $\Delta \phi$ は波線の射出角の間隔である. (14)の Weyl 積分は均質媒体の場合の表現式であったが, (15a)の GB のたし合わせによる表現は, 横方向の不均質がある場合 にも使えるよう拡張されている. ここで, 被積分関数, つまり GB の一本一本が絶対に発散しない点が重要であ り，数值的にもそのことが安定な結果をもたらす一因と なっている.

以上で，平面波を GB に置き換えることにより，一様 媒体モデル (14) より横方向不均質性のあるモデル (15a) へと拡張されることを示した。 ここで，この両者の中間 に位置し，また地震学で通常用いられる，深さ方向のみ に速度変化のある一次元モデルの場合を考えてみる. そ うすることによって，GBのたし合わせで波動場を表現 することの意味が，もっと明確になるであろう。 MADARIAGA (1984) 及び MADARIAGA and PAPADIMITRIOU (1985) は, CERVENÝ等が求めた (15a)の形が, 一次元モ デルにおける C C HAPMAN (1978) の WKBJ 法の拡張に なっていることを示した. 一次元モデルにおいては, $(15$ a) は次のように書ける.

$$
U(x, z, \omega)=\frac{i}{4 \pi} \int_{-\infty}^{\infty}\left[\frac{Q(0) c(z)}{c(0) Q(z)}\right]^{1 / 2} e^{i \omega \theta(\xi, z, p)} \frac{d p}{\eta(0)}
$$

ただし

$$
\theta(\xi, z, p)=\tau(z, p)+p x+\frac{1}{2} N(z) \xi^{2}
$$

又,

$$
\tau(z, p)=T-p x=\int_{0}^{z} \frac{\cos \phi}{c(z)} d z
$$

ここで, $\tau$ は垂直方向のみの走時であり, $\xi$ は考えている 点から波線までの水平距離, $N(z)$ は $\xi$ に対応する波面の 曲率である. GB 法では, $Q$ と $N(z)$ は平面波と円筒波の 重ね合わせとして表現されている. (12) の線型結合で係 数 $\varepsilon$ を無限大とすると, つまり平面波だけを取り出す と, 曲率は零なので $N(z)$ は零となり,

$$
U(x, z, \omega)=\frac{i}{4 \pi} \int_{-\infty}^{\infty} \frac{e^{i \omega(\tau+p x)}}{[\eta(0) \eta(z)]^{1 / 2}} d p
$$

を得る.この時, $Q$ は実数 $c \eta$ に帰着する. (16)の被積分 関数 $e^{i \omega(\tau+p x)}$ は一次元モデルでの $\phi$ 方向へ伝幡する平面 波を表しており，CHAPMAN (1978) の WKBJ 法の出発 点の式に一致する. さらに速度が深さ方向にも一様とす ると, $\eta=\left(c^{-2}-p^{2}\right)^{1 / 2}$ が一定となり， $\tau=\eta|z|$ となる ので, Weyl 積分 (14) に帰着する. 
a)

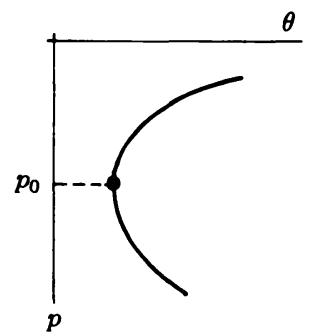

b)

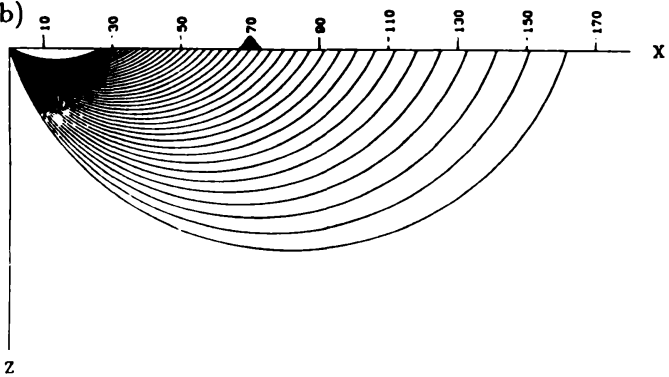

c)

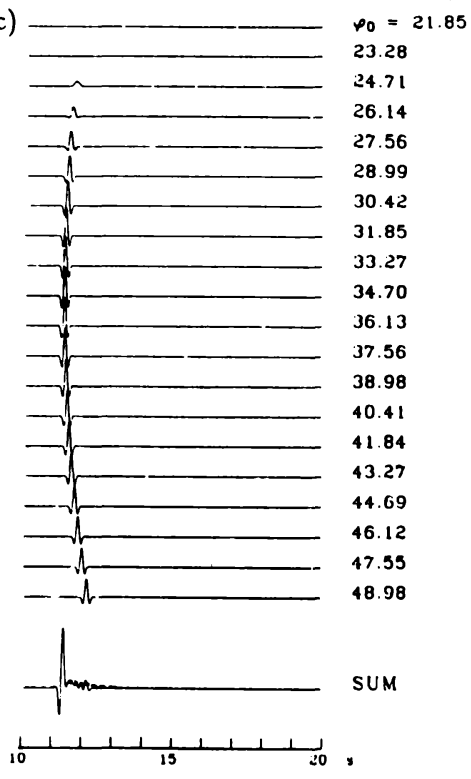

Fig. 3. a) $\theta$ curve as a function of $p$ at the horizontal distance of $70 \mathrm{~km}$ for a half space with a constant velocity gradient. b) Set of rays used to generate seismograms. c) Individual Gaussian beam contribution for the synthetic seismogram at the bottom. [Added to MAdariaga (1984)].

順序が逆になってしまったが，上に述べたことで，一 様媒体の式 (14) から, 一次元モデルの式 (16) を経て, 横 方向不均質媒体に対する式 (15a) へと平面波分解（ある いはGB 分解）が一般化されていく過程が明らかになっ たと思う，又，波線理論 ART を拡張してPRA が導か れ，そのPRA の拡張である GB を何本もたし合せるこ とで, 波動理論に基づく地震記象の形式へと近づいて いったことが理解されるであろう。一次元モデルでは波 動場を(16) のように波線パラメーターpで分解するの であるが，これは，pが波線に沿って不変に保たれると いうスネルの法則の重要な特徵に基づいている. 二次元 及び三次元モデルでは, このような不変量が存在しない ため, 平面波分解のように, 計算上の簡略化ができない. そこで GB 法では，(15)でみたように，平面波の代わり に平面波と円筒波（あるいは球面波）の組み合わせとし ての GB で分解するのである. 次章では, 一次元モデル の場合について，GB 法 (15) が従来の WKBJ 法 (16)の ような地震記象の合成法とどのような関係にあるのか を, MADARIAGA (1984) に従ってみてみることにする. この対比は, 二次元モデルなど複雑な媒体の場合, 単純 には拡張できないけれども， GB 法がどのように㗢くの かが把握できるであろう。

\section{§ 7.一次元モデルにおける例}

本章では, 一次元モデルの場合, GB 法(15) がどのよ うに波形を組み立てるのかを, WKBJ 法 (16) と比較し ながら論じることにする．まず，従来の平面波分解 (16) では, 波線パラメーター 領域を積分する形になっているが，これを小さな領域に 分けて実際の数值積分をすることになる．この積分範囲 のすべてが現実には重要なのではなくて，実はごく一部 の領域の積分しか効いてこない，その領域とは，多くの 場合 (陰のような場合は除く), 震源と観測点を結ぶ波線 に対応する波線パラメーター る. 他の部分からの寄与は, 位相が近接した部分に対し て少しずっずれているため，打ち消しあってしまう [CHAPMAN (1976)]. これを見るために(16)の表現を時 間系にもどしてみると,

$$
\begin{aligned}
U(x, z, t) & =\frac{1}{\pi} \operatorname{Re} \int_{0}^{\infty} U(x, z, \omega) e^{-i \omega t} d \omega \\
& =\frac{1}{4 \pi^{2}} \operatorname{Re} \int_{-\infty}^{\infty} \frac{1}{[\eta(0) \eta(z)]^{1 / 2}} \frac{d p}{t-\theta} \\
& \left.=\frac{1}{4 \pi^{2}} \operatorname{Re}\left[\frac{1}{[\eta(0) \eta(z)]^{1 / 2}} \frac{1}{\left|\frac{\partial \theta}{\partial p}\right|}\right]\right]_{t=\theta}
\end{aligned}
$$

となる.ここで, $\theta=\tau+p x$ である. (17) から, 時間 $t$ が ちょうど $\theta$ となる所から，すなわち，波線理論の走時に 
相当する所から波形が始まることがわかる．上式のよう に無限大の周波数域（つまり衝撃的な震源に対する応 答）に関しては，波線理論 (6) と一致する。この場合は, 波線に沿っての走時が $\theta$, そして振幅 $[c / Q]^{1 / 2}$ が $\eta^{-1 / 2}$ に対応している.こうして波線理論と波動理論が結びつ $<$.

次に，具体例として速度勾配が一定の場合について考 えてみる [MADARIAGA (1984)]。震源を表面に, 観測点 を $x=70 \mathrm{~km}$ ととる. まず, (17) の形式で地震記象を得 るには, $x=70 \mathrm{~km}$ での $\theta(p, x)=\tau+p x$ を $p$ の関数とし て計算する必要がある. $\theta$ と $p$ の関係をプロットする 之, Fig. 3a) の上うにある所で極小值をとる正の曲率を 持った放物線のような形となる。この $\theta-p$ 曲線は， $\tau$ を 計算する際の積分だけから求められ，波線の軌跡を計算 することはいっさい不必要である．この図で走時が最小 になる $p_{0}$ が, 実はフェルマーの原理に基づく波線パラ メーターに対応していることにも注意されたい，縦軸に 平行な直線を時間 $\mathrm{t}$ と共にずらしていき，この曲線との 交点を求める. (17) の積分に寄与するのは, この交点で の值である. 従って, 極小点 $\theta\left(p_{0}, x\right)$ より以前には何の 波も存在せず, $t=\theta\left(p_{0}, x\right)$ から波形が始まり, 以後は二 点で交わることになる. この $\theta\left(p_{0}, x\right)$ が ART の波線に 沿っての走時である.この点以外の交点からの寄与は, 連続して積分に効いてくるためにお互いに消し合い，実 質的にはほとんど効かなくなる．(17) の形式は，前述の ようにすべての周波数域を含んでいるので数値的な計算 には不安定が生じるし，また実際問題では意味もなくな る. 実用的には, DEY-SAKAR and CHAPMAN (1978)のよ うに，有限の周波数域にするため，何らかの関数との畳 み込みを行い積分域をなめらかにしなくてはならない。 例えば，ČERVENÝ (1983) の提唱するように, Gabor 波 群を震源関数 $s(t)$ として選べば, (17) は

$$
\tilde{\mathrm{U}}(x, z, t)=s(t) * U(x, z, t)
$$

$$
=\frac{1}{4 \pi^{2}} \operatorname{Re} \int s(t) *\left\{\frac{1}{[\eta(0) \eta(z)]^{1 / 2}} \frac{1}{t-\theta}\right\} d p
$$

ただし

$$
s(t)=\exp \left[-\left(\frac{\omega_{0} t}{\gamma}\right)^{2}\right] \cos \omega_{0} t
$$

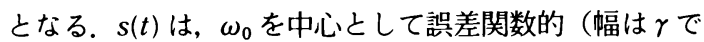
決まる) にバンドパスフィルターをかけた周波数域を持 つ. (18) は畳み込み*の操作によってなめらかになり, 数值的に安定なものとなる，一次元モデルの場合も，極 値 $p_{0}$ の近傍からの寄与のみを計算していけば十分であ る. さて, 極値 $p_{0}$ から遠ざかるにつれて,つまり実際の 波線から離れるにつれて，その寄与が急激に小さくなる わけであるから，実際の波線からの距離 $\xi$ が大きくなる
につれて重みが急激に減少するようなフィルターをか け，余計な積分領域を落としてしまいたくなる，一次元 モデルの場合の GB 法 (15a) と WKBJ 法 (16) を比べる と, 直ちに次のことがわかる、GB法においては

$$
\exp \left[-\frac{\omega}{2} I_{m} N(z) \xi^{2}\right]
$$

というフィルターをWKBJ 法 (16) のひとつひとつの平 面にかけた形になっており，この形は，上で述べた物理 的要請にもかなっている，さらに，上の形のフィルター では，周波数が高くなるほどその幅が狭くなる，言い換 えれば，寄与する範囲が狭くなり ART に近くなること がわかるであろう。このフィルターの形は, 勝手に考え 出されたものではなく, dynamic ray-tracing (8) の複 素数解をとることによって, 自然な形で導入されたもの である. ČRVENÝ等はもともと, ART の拡張として GB 法を導入したわけなので，(11b) の円筒波源（あるいは 球面波源）の初期条件が基本であり, 特異点の問題を解 消するために平面波（11a）をいわば補正項として加えた と考えられる.上でみた WKBJ 法との比較では，この見 方は全く反対に，平面波のたし合わせから始まって，そ れに円筒波を加えてフィルターをかけた形になってい る.

これまで，WKBJ 法にフィルターをかけた方法が GB 法に帰着することを示したが，その合成法を詳しく見て みることにする．まず，Fig. 3b) のように波線をトレー スする．次に(8) を平面波と円筒波の二つの初期条件で 波線に沿って解いていく．その二つの解を(12)のように 複素数係数で結びつける. 最後に (15b)のようにたし合 わせる. Fig. 3c) には，ひとつひとつのビームの奇与と そのたし合わせの結果を示す． 波線の出射角 $\phi_{0}$ が Fig. 3a) のpに対応し，二つの図か滵接に関係することが示 される. GB 法は Fig. 3a) に上述のフィルターをかけた ことになるので，実際の波線 $p_{0}$ にあたる $\phi_{0}=36.16^{\circ}$ に おいて，極値をとる. フィルターの効果によって，振幅 もこれに対応するビームがいちばん大きく，それから離 れるにつれて小さくなっていくことが Fig. 3c) に示され ている．虚数部を零にして平面波のみの極限の場合を考 えると, GB 法はWKBJ 法, Fig. 3a) に㷌着される. Fig. 3a) の方法でも，たし合わせる際に極值 $p_{0}$ 以外では位相 が少しずつずれているので，振幅が減衰していかなくて む, 理論的には互いに消し合うはずである。実際には, 有限の $p$ の間隔を取っていくのでうまく消し合わない ことがある. 極值 $p_{0}$ の点より振幅が減衰する GB 法で はもっと安定した結果が得られる。

Fig. 4 では, さらに複雑な焦点の場合を Now ACK and AKI (1984) の例に従って考察してみる. WKBJ 法 (16) 


\section{LAYER OVER GRADIENT}
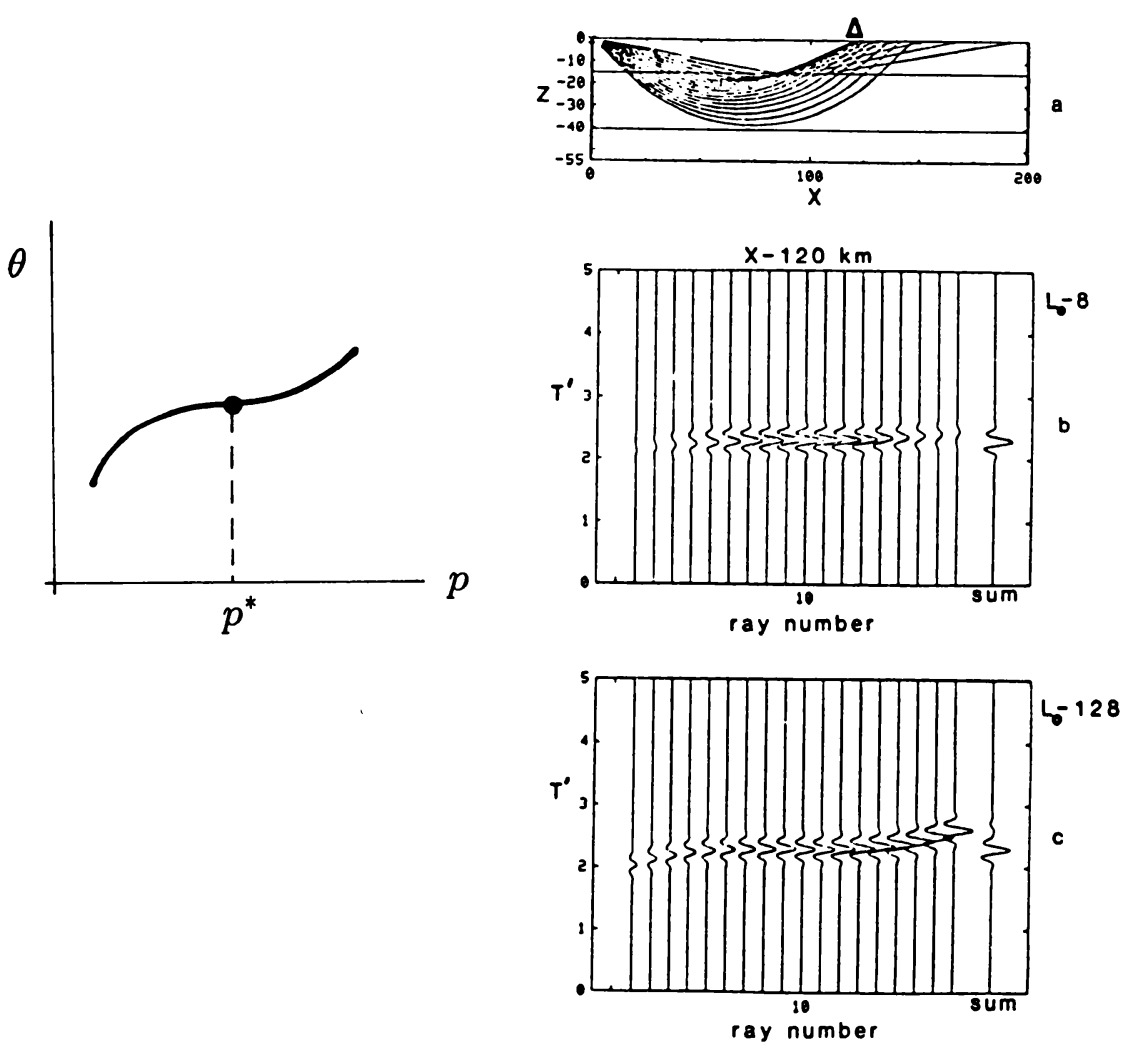

Fig. 4. $\theta$ curve as a function of $p$ at the horizontal distance of $120 \mathrm{~km}$ corresponding to a caustic for a homogeneous layer over half space with a constant velocity gradient. The two right bottom figures show individual Gaussian beam contribution for the synthetic seismograms in the right with two different beam parameters. [Added to Now Аск and Акı (1984)].

では，焦点は $\theta-p$ 曲線上の変曲点 $p^{*}$ に対応することに なり, 普通の到着波に比べて振幅がずっと大きくなる. もちろん位相も異なるが，それらについては CHAPMAN (1978)を参照されたい. この特徴と GB 法でのたし合わ せが対応していることは，この図から明らかである.

Fig. 4 ではさらに, 虚数部の大きさによってたし合わせ の様子がどのように変化するかも比較している， $L_{0}=8$ は, 大きな虚数部，つまり幅の狭いビーム（フィルター） を用いた場合で, $p^{*} に$ 対応する実際の波線とその近傍の 数本のビームのみが効いてくる. 一方 $L_{0}=128$ は, 小さ な虚数部，つまり幅の広いビームを用いた場合で, WKBJ 法に近くなる.この場合には, 多くのビームから の寄与が効いてくる. 前述のように, 実際の波動場を決 めるのは, 極值 (焦点では変曲点 $\left.p^{*}\right)$ に対応するビーム とそのごくまわりのビームのみであるので, ビームの幅 を狭くして有効なビームの数を咸らした方がよいような 感も与える. ところが，たし合わせるビームの数が少な
すぎると，お互いにうまく消し合わず数値的誤差が大き くなる．ビームの幅を零に近づいていく極端な場合を考 えると，ARTに近づいてしまい，焦点では波線の広が り $Q$ は零に近づき, 振幅は発散してしまう。この点につ いては次章で述べる。

なお，焦点を波が通過すると， $\pi / 2$ の位相の進みが生 じる. 表面波が震央や対蹠点を通過する際のポーラー・・ フェイズ・シフトもこの一種である. GB 法では, 複素 平面上で $Q$ の位置を追っていき, 位相の進みが初めから どれだけかをたどれば，この効果を取り入れることもで きる.このことについては, Chapman and Drummond (1982) の $\mathrm{KMAH}$ 指数を参照されたい.

\section{§ 8. 問題点と今後の展望}

これまで見てきたように，GB 法は一次元モデルでは WKBJ 法の自然な拡張であり，その形式化が波線の軌跡 に基づくことから, より複雑な横方向不均質性のあるモ 
デルにも自然に適用される，何本かの波線をトレースす るだけでよいので，たとえ伝播距離が長くなっても素早 く計算できる.

以上は, 二次元スカラー波という最む簡単な場合のみ を考えてきた．三次元モデルになると表現がより複雑に なるし，また弾性波を考えると波の偏向面といったもの も考慮せねばならない，さらに，連続的な媒質ではなく， 速度等に不連続な境界面がある場合には，反射・透過係 数なども考えなくてはいけない，波線そのあのについて は，お馴じみのスネルの法則でよいが，波線の広がり等 を表す変数 $p や Q$ については, 境界面でどのように変 化するか新たに計算する必要がある，P-SV 波の場合で は特に複雑であることは明らかである，以上のような一 般的な場合についての形式化は ČERVENÝ (1985a) のま とめを参照されたい，今まで述べてきた基本概念を理解 できれば,こういった一般化の部分の理解はやさしいは ずである.ささらに，地震波，つまりダブルカップルから の波は方位特性があるが，これは波線理論の場合と同じ なので, АKI and RICHARDS (1980)などの形式をそのま ま用いればよい。

あうひとつ面倒なのは速度構造のモデルの作り方で, (8) でみたように振幅は速度の二階微分と関係してくる ので注意が必要である.これについては C ERVENÝ (1987) に良いまとめがある. さらに, CeRvenצ et al. (1988)では実際の計算の仕方が記述されており, 又, ソ フトゥェア・パッヶージあ提供されているので，これを 少し変更するだけで広く一般に応用することができるで あろう。ここ数年来, 数多くの精度のテストや各種の応 用がなされてきたが，これについてはČERVENÝ (1985b) に抜粋されているので，ここではくり返さない，それ以 後の発展としては，異方性媒体への GB 法の応用 $\left[\mathrm{GAJ}_{\mathrm{AJ}}\right.$ EWSKI and PŠENČíK (1987), HANYGA (1986)] や, 波線の 椇動法による効果的な計算方法の開発 [FERRA and MADARIAGA (1987)]などが挙げられる.

さて, 最も重大な未解决の問題は, いかに平面波と円 筒波（三次元では球面波）をたし合わせるか，つまり (12) の係数 $\varepsilon$ を決めるかである. 特に, 虚数部, つまり ビームの幅の選択は, 結果を大きく左右する. 前章のよ うな一次元モデル， あるいは不均質性の比較的弱い場合 [例えば YomoGIDA and AKI (1985) の表面波の場合な ど]であれば, ČERVENÝ et al. (1982)などが提唱してい る係数の值で大体良い結果が得られることが, 各種の計 算で示されている，また，多少の係数の変化では, 結果 にあまり影響がない，ところが，不均質性が大きくなっ て波線のふるまいが複雑になってくると，一気に事態は 変わってしまう，特に，焦点や陰といった GB 法が有効
であると主張される特異領域では，この係数をどう選ぶ かで好みどおりの地震記象が勝手にできてしまう，Calaveras 断層沿いの低速度層による異常振幅を GB 法を 用いて説明しょうとした CORMIER and SPUdich (1984) のような例では, 波線が複雑にからみ合い，係数の取り 方ひとつで結果は何とでもなってしまう。つまり，強い 不均質性が入ってくると，GB 法は確かな計算方針が立 てられなくなってしまう。 ChAPMAN and DRUMmond (1982) の Maslov 法にしても同様で, 平面波解と球面波 解の組み合わせの仕方がやはりはっきりしていない，今 までの GB 法の研究は，この点を無視して安易に使われ てきすぎたと思う.

今後は, 問題となっている係数の物理的意味を考える か，あるいは何か別の方法と組み合わせて係数にあまり 依存しない形式化を行うことが望まれる。 KLIMEŠ (1984)は，与えられた波面において最適なパラメ一 ター，つまり係数の形がどうなるかについて理論的な考 察を行っているが，それ以来，この問題を正面から扱っ た研究は目につかなかった. 最近, WEBER (1988)は, 問 題となっている係数 $\varepsilon$ をビームが通過していく途中の不 均質性の大きさによって調節することで，比較的安定し た結果が得られることを数值実験によって示した．不均 質性が弱い所ではビームの幅を広くし，強い所では狭く する．物理的に考えれば，有限の周波数の波はその波長 のスケールで媒体をフィルターしながら伝播していくわ けであるから，ビームの幅のこのような選択の目安は妥 当である.

一方, BenITes and AKI (1989) は, 最近注目を集めて いる境界積分法を GB 法と組み合わせることで，上述の 係数依存性をなくす方法を開発した，彼らは，境界面 （あるいは表面）に力源を散らばせ，そこからの波を $\mathrm{GB}$ 法によって入射波, 反射波及び透過波として表現し， 各々の力源の強さは境界条件（変位及び応力）を最小二 乗法的に満足するように決めている。 この方法を用いる と, 結果は係数 $\varepsilon$ にとんどよらないことが, いくつか の計算例によって確められた。一本一本のビームを独立 に扱うのではなく，波動場を記述する多数のビームを全 体として取り扱うことで係数の効果をなくすわけであ る.この方法は，次の二点ですぐれている，強い不均質 性があっても使えること．次に，表面や境界面近くの波 動場も計算できることである. PRA の (9) の形を思い出 すと, 波動場を波線の近傍領域へ外挿する際には媒体が なめらかでなくてはならない. ところが，地震学におけ る観測点はほとんど表面にあるので，(9) の PRA，ある いはGB 法を実際にはどのように適用したらよいのか はっきりしていない，表面近くでは波は複雑に干渉しあ 
う. BENITES and AKI (1989) の方法は，こういった状況 でも直接適用できる．彼らはまだ $\mathrm{SH}$ 波の場合について しか取り扱っていないので, より複雑な $\mathrm{P}-\mathrm{SV}$ 波の場合 によ゙れだけ安定した結果が得られるかが課題であろう.

\section{§9.おわりに}

Paraxial ray 近似 (9) は, 従来の波線理論の自然な拡 張として重要であり，その利用価値も高い，焦点や陰な どの領域以外では，おっと利用されるべきである．本論 の後半では, 焦点や陰などの場合にも使用できる GB 法, 特にそのたし合わせが, 従来用いられてきた平面波 分解の概念に結びついていることを，特に一次元モデル の場合を例にとって示した. 有限の周波数の波ではエネ ルギーが波線の外へ染み出すという GB の物理的着想は 正しい. しかし, 現実の定式化においては, 变数 $P や Q$ を単に実数から複素数に置き換えたという程度の数学的 裏付けしかない．エネルギーの波線からの染み出しぐあ い,つまりビームの幅をどのように決めればよいかにつ いては，まだ何もわかっていないし，従って，それを決 める係数 $\varepsilon$ の値の取り方いかんによって結果が著しく変 わってしまうことを指摘した。

今後は，このビーム幅の係数を経験的に決めるのでは なく，確固とした物理的裏付けの上に計算していかなく てはならない，それには，個々のビームを独立に波線近 傍領域へ外挿していくC ERVEN等の元々の方針を捨て, ビーム同士のつながりを積極的に考えなくてはならない であろう，例えば，何本かの波線上のある時刻の点を結 びつけると，それがその時刻の波面に対応する．PRAや GB 法は, (7) の上うに二次のティラー展開で波線以外の 領域の波動場を考えた．上のように多く波線上の点から もっと高次の精度で波面を全体として決めることは自然 にできる．このような方法を使えば，エネルギーの波線 からの染み出しの程度, すなわち, ビームの幅ももっと 具体的に与えられるであろう。

Fig. 1 に示した地震学で扱う広範な分野は, コン ピューターがいくら速くなっても直接に解くことはでき ない，GB法やそれに関する手法の確立は，一次元モデ ルに縛りつけられていた地震学者を, 横方向不均質性が 本質的に係わってくる多くの現象の解明へと向かわしめ る第一級の研究であると思う.

\section{References}

AкI, K. and P. G. Richards, 1980, Quantitative Seismology, W. H. Freeman, 932 pp.

Babich, V. M. and A. S. Alekseyev, 1958, On the ray method of the computation of the intensity of wave fronts (in Russian), Izv. Akad. Nauk. USSR, Geophys. Ser. No. 1, 9-15.

Benites, R. and K. Акı, 1989, Boundary IntegralGaussian beam method for seismic wave scattering: SH waves in 2-D media, J. Acoust. Soc. Am., in press.

Born, M. and E. Wolf, 1980, Principles of Optics, 6th ed., Pergamon Press, 808 pp.

Cervený, V., 1983, Synthetic body wave seismograms for laterally varying layered structures by the Gaussian beam method, Geophys. J. Roy. Astr. Soc., 73, 389-426.

CERVENY, V., 1985a, The application of ray tracing to the numerical modeling of seismic wave fields in complex structures, in "Seismic Shear Waves, Part A: Theory", ed. by G. Dohr, Geophysical Press, 1124.

ČervenÝ, V., 1985b, Gaussian beam synthetic seismograms, J. Geophys., 58, 44-72.

CeRVEnÝ, V., 1987, Ray tracing algorithms in threedimensional laterally varying layered structures, in "Seismic Tomography", ed. by G. Nolet, D. Reidel Publishing Comp., 99-133.

Červený, V., L. Klimeš and I. Pšenč́́x, 1984, Paraxial ray approximations in the computation of seismic wave field in inhomogeneous media, Geophys. J. Roy. Astr. Soc., 79, 89-104.

Červený, V., L. KlimeŠ and I. PŠEnČík, 1988, Complete seismic-ray tracing in three-dimensional structures, in "Seismological Algorithms", ed. D. J. Doornbos, Academic Press, 89-168.

Červený, V., M. Popov and I. Pšenčír, 1982, Computation of wave fields in inhomogeneous mediaGaussian beam approach, Geophys. J. Roy. Astr. Soc., 70, 109-128.

Červený, V. and I. PŠenčík, 1983, Gaussian beams and paraxial ray approximations in three-dimensional elastic inhomogeneous media, J. Geophys., 53, 1-15.

Chapman, C. H., 1976, A first motion alternative to geometrical ray theory, Geophys. Res. Lett., 3, 153156.

Chapman, C. H., 1978, A new method for computing synthetic seismograms, Geophys. J. Roy. Astr. Soc., 54, 481-518.

Chapman, C. H., 1985, Ray theory and its extensions: WKBJ and Maslov seismograms, J. Geophys., 58, 27-43.

Chapman, C. H. and R. Drummond, 1982, Body-wave seismograms in inhomogeneous media using Maslov asymptotic theory, Bull. Seism. Soc. Am., 72, S277-S317.

Claerbout, J. F., 1985, Imaging the Earth's Interior, Blackwell, $398 \mathrm{pp}$.

Cormier, V. F. and P. Spudich, 1984, Amplification of ground motion and wavefront complexity in fault zones: examples from the San Andreas and Cala- 
veras Faults, Geophys. J. Roy. Astr. Soc., 79, 135-152.

Deschamps, G. A., 1971, The Gaussian beams as a bundle of complex rays, Electr. Lett., 7, 684-685.

Dey-Sarkar, S. K. and C. H. Chapman, 1978, A simple method for the computation of body-wave seismograms, Bull. Seism. Soc. Am., 68, 1577-1593.

Ferra, V. and R. Madariaga, 1987, Seismic waveform modeling in heterogeneous media by ray perturbation theory, J. Geophys. Res., 92, 2697-2712.

GAJEWski, D. and I. PŠEnčík, 1987, Computation of high-frequency seismic wavefields in 3-D laterally inhomogeneous anisotropic media, Geophys. J. Roy. Astr. Soc., 91, 383-411.

HanygA, A., 1986, Gaussian beams in anisotropic media, Geophys. J. Roy. Astr. Soc., 85, 473-503.

Karal, F.C. and J.B. Keller 1959, Elastic wave propagation in homogeneous and inhomogeneous media, J. Acoust. Soc. Am., 31, 694-705.

KLIMEŠ, L., 1984, Expansion of a high-frequency timeharmonic wavefield given on an initial surface into Gaussian beams, Geophys. J. Roy. Astr. Soc., 79, 105-118.

Kogelnik, H., 1965, On the propagation of Gaussian beams of light through lens-like media including those with a loss or gain variation, Appl. Opt., 4, 1562-1569.

Landau, L. D. and E. M. Lifshitz, 1975, The Classical Theory of Fields, 4th ed., Pergamon Press, 402 pp.

MADARIAGA, R., 1984, Gaussian beam synthetic seismograms in a vertically varying media, Geophys. J. Roy. Astr. Soc., 79, 589-612.

Madariaga, R. and P. Papadimitriou, 1985, Gaussian beam modeling of upper mantle phases, Ann. Geophys., 3, 799-812.

Now ACK, B. and K. Akı, 1984, The 2-D Gaussian beam synthetic method: testing and applications, J. Geophys. Res., 89, 1466-1494.

Thomson, C. J. and C. H. Chapman, 1985, An introduction to Maslov's asymptotic method, Geophys. J. Roy. Astr. Soc., 83, 142-168.

WEBER, M., 1988, Computation of body-wave seismograms in absorbing 2-D media using the Gaussian beam method: comparison with exact methods, Geophys. J., 92, 9-24.

Yомоgida, K. and K. Акı, 1985, Waveform synthesis of surface waves in a laterally heterogeneous Earth by the Gaussian beam method, J. Geophys. Res., 90, 7665-7688. 